\title{
Water Table Depth, Surface Saturation, and Drought Response in Bog Turtle (Glyptemys muhlenbergii) Wetlands
}

\author{
Jeffrey B. Feaga • Carola A. Haas • James A. Burger
}

Received: 23 September 2011 / Accepted: 13 August 2012/Published online: 7 October 2012

(C) The Author(s) 2012. This article is published with open access at Springerlink.com

\begin{abstract}
The bog turtle (Glyptemys muhlenbergii) is known to select wetland areas that are near water with deep mud, but water table dynamics in their habitats have not been well described. We installed and monitored shallow groundwater wells to evaluate hydrology over a continuous 28-month period on six wetlands known to be frequently used by bog turtles and six similar wetlands not known to be used. Overall, water tables remained high, with mean monthly depth to the water table for all 12 wetlands varying between $-1 \mathrm{~cm}$ and $-35 \mathrm{~cm}$ below the soil surface. Wetlands frequently used by bog turtles had higher mean water tables and surface saturation than wetlands not known to be used, particularly during summer months. Differences in mean water table $(17 \mathrm{~cm})$ and saturation $(25 \%)$ were greatest during southwestern Virginia's 2008 drought. A differential remained after the resumption of normal rainfall, demonstrating the importance of groundwater recharge to bog turtle wetlands. Relatively small differences in water table hydrology have the potential to affect bog turtle biology and wetland use because bog turtles primarily use the top $15 \mathrm{~cm}$ of the soil and select saturated locations even when the availability of saturated soil is limited.
\end{abstract}

Keywords Fen · Habitat use $\cdot$ Hydroperiod $\cdot$ Groundwater . Monitoring well $\cdot$ Virginia

\section{J. B. Feaga $(\bowtie) \cdot$ C. A. Haas}

Department of Fish and Wildlife Conservation,

Virginia Tech,

Blacksburg, VA, USA

e-mail: feaga05@vt.edu

\section{J. A. Burger}

Department of Forest Resources and Environmental Conservation,

Virginia Tech,

Blacksburg, VA, USA

\section{Introduction}

The geographic range of the bog turtle (Glyptemys muhlenbergii) in the south extends from southwestern Virginia to northern Georgia, primarily within the Blue Ridge Physiographic Province. The type of wetlands used by bog turtles have been classified as mountain fens (Richardson and Gibbons 1993; Herman and Tryon 1997). The hydrologic conditions of wetlands inhabited by bog turtles have been qualitatively described as spring seeps, spring-fed meadows or floodplains with moderate amounts of slow-moving water. These wetlands have interspersed wet and dry pockets, but generally lack areas of deep standing water (Bury 1979; Chase et al. 1989; Lee and Norden 1996; Buhlmann et al. 1997).

Fens are differentiated from other wetland types primarily by having groundwater-dependent hydrology and secondarily by characteristic vegetation and soils resulting from that hydrology (Bedford and Godwin 2003). Fens often display multiple seepage areas and may show both upward and downward vertical gradients within the same wetland system (Amon et al. 2002). Temperate zone fens are usually found on land that is slightly sloped, resulting in little inundation. Because of groundwater inflow, fens generally have more moderate water table fluctuations than wetlands dependent on periodic flood events or precipitation (Hunt et al. 1999). Many fens in the southern Appalachians contain vegetation that is typical of acidic bogs such as sphagnum moss, which has been associated with bog turtle nesting (Mitchell 1994; Ernst and Lovich 2009). Fen recharge areas are difficult to delineate, but it is expected that the larger the recharge area, the more stable the hydrology (Bedford and Godwin 2003).

The effects of water level and hydroperiod on turtles have been assessed in wetlands with primarily surface waterdriven hydrology (Gibbons 1990; Skidds and Golet 2005; Roe and Georges 2008). However, few large-scale wildlife studies have been completed in wetlands where soil 
saturation and not inundation is of primary importance. Within the southern range of the bog turtle, there are many wetlands that upon a brief visual inspection appear to have suitable characteristics to support bog turtles; however, bog turtles have been encountered in only a small proportion of these wetlands. Because the bog turtle is rare, federally protected, and occupies wetlands that are under threat by numerous activities that can change hydrology (Buhlmann et al. 1997), development of a methodology allowing for the identification of suitable bog turtle habitat through assessment of local hydrology is a worthwhile effort.

Although bog turtles use portions of wetland habitats with the deepest and softest mud (Carter et al. 1999), the species is more associated with interspersed wet and dry areas than they are with expansive open water areas (Chase et al. 1989). Often, the interspersion of soft mud and water pockets within a matrix of drier soils is caused by microtopography resulting from plant growth or livestock activity. Bog turtles use the wet pockets created by livestock hooves (Tesauro and Ehrenfeld 2007). Associating water table characteristics with the availability of accessible saturated soil is an important link between hydrology, bog turtle biology, and their use of particular areas within wetlands. Drought can limit use by wetland dependent species, so observing hydrology during a drought may provide important insights into a wetland's suitability for long-term use by bog turtles.

The purpose of this study was to evaluate water table hydrology and surface saturation in wetlands frequently used by bog turtles and compare their hydrology to nearby wetlands that were not known to be used. We hypothesized that wetlands frequently used by bog turtles would differ from wetlands not known to be used in the following ways: 1) Water tables would be close to the surface in wetlands frequently used by bog turtles, particularly during hot and dry periods when hydrologic budgets are typically at a deficit; 2) Temporal fluctuation of the water table would be less variable in frequently used wetlands; and 3) Wetlands frequently used by bog turtles would have greater extent of surface saturation than wetlands not known to be used.

\section{Study Area and Methods}

\section{Study Area}

In coordination with the Virginia Department of Game and Inland Fisheries (VGIF) and the National Park Service (NPS), 12 wetlands located in Floyd and Patrick counties within the southern Blue Ridge sub-province of Virginia were selected for this investigation (Fig. 1). Bog turtles were documented on multiple occasions at six of the wetlands during surveys from 1987 and 2009. Bog turtle nests were found at all six of these inhabited wetlands, and juvenile bog turtles have been captured at five of the six wetlands. The other six study wetlands were apparently uninhabited by bog turtles and were selected based on the presence of hydric soils, evidence of surface saturation, and their similarity to the inhabited wetlands with reference to landscape position, slope, and vegetation.

Study wetlands were irregularly shaped with multiple core areas of saturation due to variations in surface elevation. Valley slopes where wetlands occurred were between 0 and $3 \%$ as determined with Digital Elevation Maps and confirmed with a clinometer. The longitudinal axes of the study wetlands were not always oriented in the same direction as the valley slope, and wetland slopes along these axes were between 3 and $5 \%$. Geology and soil types are discussed in Feaga (2010). All study wetlands were currently or historically (within the last 15 years) used for agriculture with exception of one wetland, which supported a mature forest. We estimated wetland size using ArcMap 9.2, aerial photography, and first-hand knowledge of the vegetation, hydrology, and soil conditions at each study wetland. Each wetland was between 0.1 and 1.2 ha in size with a mean and median size of approximately 0.5 ha. A wetland was considered a discrete study site when it was bounded by greater than $100 \mathrm{~m}$ of nonwetland, was bounded by the convergence of hydrology into a stream, or was separated from another site by a road. The study wetlands were situated along a narrow ellipse oriented north-south that spanned $24 \mathrm{~km}$. The median distance between successive wetlands along the ellipse was $1,250 \mathrm{~m}$. The shortest distance between study wetlands was $35 \mathrm{~m}$, and these were separated by the two-lane, frequently travelled Blue Ridge Parkway. The longest distance between a wetland not known to be used by bog turtles and any used wetland (not necessarily a wetland included in this study) was approximately 2,700 $\mathrm{m}$, which is within the known dispersal distance of bog turtles (Carter et al. 2000).

For data analyses, we refer to the initial six study sites with bog turtle occurrences as "frequently used" wetlands because they have a record of multiple turtles of various age classes. We refer to the initial six study sites that were apparently uninhabited by bog turtles as wetlands "not known to be used." Together these two groups of six comprise the a priori wetland grouping because they were established at the onset of the study.

Ecological surveys designed to determine whether a species occupies a defined habitat area have inherent error associated with non-detection of the species when the species is actually present. This error is a function of the rarity of the species, how the species uses its habitat, how conspicuous the species is, and the density of the species on the survey site (Gu and Swihart 2004). The bog turtle is a species that is difficult to detect in surveys because the animals are small and inconspicuous in their coloration and behavior (Somers and Mansfield-Jones 2008). Following the identification of the a priori wetland groups, we continued to survey in wetlands not known to be used by 


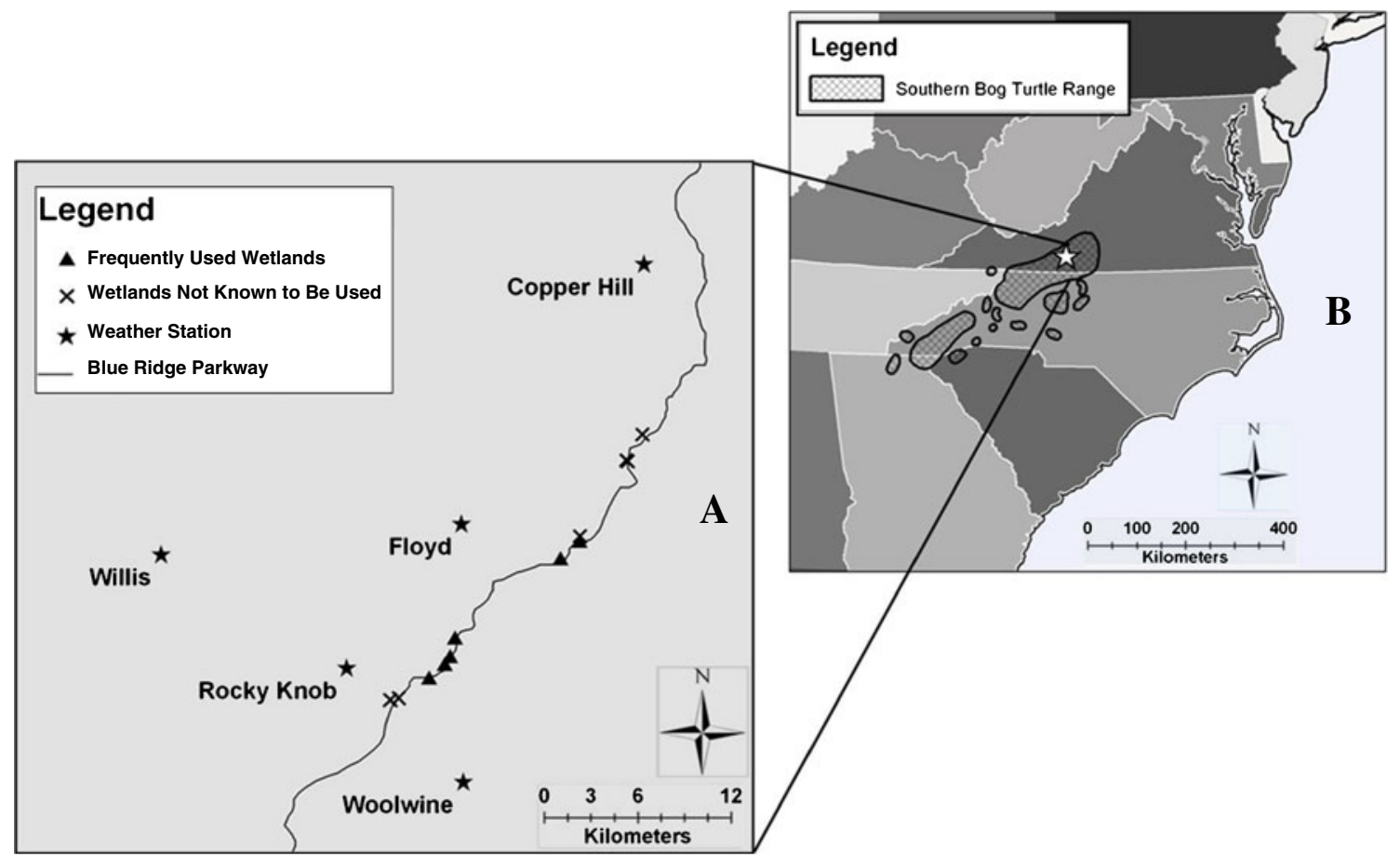

Fig. 1 Study location in the southern Blue Ridge sub-province of Virginia. Panel B shows the southern range of the bog turtle (Natureserve 2009). Panel A shows the weather stations where rainfall data were recorded and the locations of a priori wetlands that were either frequently used by bog turtles or not known to be used. Precise wetland locations are not given because of the federal and state protected status of the bog turtle and the risk of illegal collection. Symbols for two wetlands not known to be used are in close proximity and are indistinguishable bog turtles to reduce the risk of misclassification, and we also surveyed frequently used wetlands to establish theoretical expectations of turtle captures given our survey effort. During the summer of 2007, groups of 1 to 3 trained technicians employed hand surveys (peering through vegetation and probing the soil with a wooden stick) for a total of 32 person hours at a priori wetlands not known to be used and 106 person hours at frequently used wetlands. No turtles were captured at wetlands not known to be used, while surveys at frequently used wetlands resulted in an average ( \pm SE) capture rate of $2.6 \pm 1.2$ turtles per 10 person-hours of search (or 1 turtle per 3.8 person-hours). We also used cage traps to survey for bog turtles. Trap doors were hinged so they could swing inward but not out. During the summers of 2007 and 2008, we trapped for 10,536 trap hours and 16,296 trap hours at a priori wetlands not known to be used and frequently used wetlands, respectively. No turtles were captured at wetlands not known to be used, while trapping at frequently used wetlands resulted in an average $( \pm$ SE) capture rate of $1.9 \pm 0.75$ turtles per 1,000 trap hours (or 1 turtle per 526 trap hours). Because 11 out of 12 study wetlands were dominated by herbaceous vegetation and surveys were completed by the same trained technicians, there is no reason to assume large differences in detection probability between these two groups of wetlands. Although our survey effort was not applied equally among the study wetlands, we point out that in addition to organized bog turtle surveys, many hours of "unofficial" bog turtle surveys occurred on study wetlands while completing other tasks such as hydrologic measurements. Thus, we are confident the differences in observations and captures of bog turtles reflected real differences in use among wetlands.

At the end of the study, the bog turtle use status of the a priori wetlands group was modified to incorporate new information obtained from 2007 through 2009. In the summer of 2008 , a concurrent radiotelemetry study revealed that one adult male bog turtle moved approximately $300 \mathrm{~m}$ from a frequently used wetland to an a priori wetland not known to be used. This turtle returned to the frequently used wetland after approximately three months and remained there through 2009. In June 2009, a juvenile male bog turtle was encountered by chance (not an organized survey or telemetry) while measuring water levels in the only completely forested a priori wetland not known to be used. This turtle remained in the forested wetland until the spring of 2010 when it began to move downstream until radio contact was lost. Located approximately $2,700 \mathrm{~m}$ from the nearest known wetland with bog turtles present, the forested wetland had been surveyed for bog turtles with no success by National Park Service biologists numerous times in the decade before this study. 
For the remainder of our analysis, we refer to the two a priori "not known to be used" wetlands where singular occurrences of bog turtles were recorded as "transiently used." Together, the "transiently used" wetlands, the remaining "not known to be used" wetlands $(n=4)$, and the original "frequently used" wetlands $(n=6)$ comprise the post hoc wetland grouping. We justify using post hoc wetland groupings and the term "transiently used" wetlands because this grouping acknowledges that biologically real differences in hydrology may exist between wetlands that are used frequently by turtles at multiple life history stages, wetlands that are used occasionally, and those that are not known to be used at all. Further, we emphasize that the post hoc wetland groupings were formed before any statistical analyses began on either post hoc or a priori wetlands.

\section{Rainfall Conditions}

We used five weather stations that generally surrounded the study wetlands (stations were between three and $18 \mathrm{~km}$ from study wetlands) to gauge rainfall during the study and to summarize long-term conditions before the study (National Weather Service 2010). Multiple stations were used so that average rainfall conditions throughout the mountainous area could be estimated (Fig. 1). We considered precipitation to be uniform over the entire study area, although localized precipitation from small storm cells is common in the summer. Monthly and annual precipitation data were plotted and compared to the long-term average (56 to 73 years depending on station) monthly and annual precipitation data.

The Palmer Hydrological Drought Index (PHDI) for Region Six for the years from 1895-2009 (National Climatic Data Center 2010) was used to describe drought severity in the study area. PHDI values from -2.0 to $-3.0,-3.0$ to -4.0 , and $<-4.0$ indicate moderate, severe, and extreme drought, respectively. Yearly PHDI data were calculated by averaging monthly PHDI data over years. The probability of exceeding a given yearly PHDI value was calculated using the cumulative distribution function on the normally-distributed PHDI yearly data.

\section{Characterization of the Hydrology}

In the spring and early summer of 2007, we installed 38 shallow groundwater monitoring wells at each of the 12 study wetlands to measure depth to the water table. More wells were used in wetlands where seeps resulted in complex wetland shapes and multiple saturated areas. We placed wells generally along the wetland's longitudinal gradient, away from streams and channelized flow, and in the most saturated areas as we felt that these locations would characterize the hydroperiod of the wetland during the driest seasons and during drought. We only placed wells in areas of sufficiently deep soil $(>60 \mathrm{~cm})$ so that the well could provide data during dry periods and withstand potential trampling by grazing livestock.

Wells were constructed of 3.8-cm outside diameter PVC pipe with factory-cut $0.025-\mathrm{cm}$ horizontal slots spaced at $0.5 \mathrm{~cm}$ over the entire length from the bottom end cap to the top of the riser. Boreholes used for well installation were dug using an 8.9-cm diameter mud auger. The annular space between the pipe and borehole was filled with mediumgrade ( 0.25 to $0.5 \mathrm{~mm}$ diameter) sand. Well depth was determined by refusal on bedrock or large gravel, or by $140 \mathrm{~cm}$ depth, whichever was shallower. Average depth to the bottom of the 51 groundwater wells $( \pm \mathrm{SD})$ was $81.1 \mathrm{~cm} \pm 26.7 \mathrm{~cm}$. The average depth to a gravel layer was $54.7 \mathrm{~cm} \pm 16.6 \mathrm{~cm}$. A layer of gravel and cobble material that caused auger refusal was encountered for 30 of the 51 wells. The average depth of refusal on these materials was $62.5 \mathrm{~cm} \pm 7.6 \mathrm{~cm}$. Saprolitic material was encountered while augering wells in three wetlands (two frequently used by bog turtles, one not known to be used). The depth of the transition from dark colored, organically enriched soil to subsoil was variable and occurred at approximately 32 to $55 \mathrm{~cm}$. Few developed horizons were encountered below the surface, as the alluvial wetland soils lacked structure and contained little clay $(<10 \%)$ based on field texturing.

Depth to the water table was determined with a tape measure. We referenced depths to the water table as the distance from the local ground surface to the water surface within the well; thus, the depth from the ground surface was a negative value. We measured groundwater wells on 135 events between 11 June 2007 and 11 September 2009, encompassing a period of 28 months. Measurements of the depth to the water table were made every two to three days from May-August, every two weeks from SeptemberOctober, and approximately once each month in NovemberApril. To improve our estimate of the actual depth to the water table, measurements were made more frequently during the summer when water tables are more variable in many wetlands throughout the study region (Shaffer et al. 2000).

\section{Surface Saturation}

On six events between 29 August 2008 and 11 September 2009, we measured saturation in the vicinity of all groundwater wells. Surface saturation was measured using a point intercept method at $1 \mathrm{~m}$ intervals out to $5 \mathrm{~m}$ in each of the cardinal directions. Points were recorded as saturated if there was open water or if the soil was wet enough to drip by gravity if suspended, or similarly if a small hole created in the soil with the end of a broomstick immediately filled with water. Depth to the water table in wells was measured concurrently with the estimation of surface saturation. 


\section{Statistical Methods}

The response of the water table to rainfall over the 135 measurement events was first investigated graphically to identify any obvious patterns. For statistical analyses, event measurements of the depth to the water table were averaged over months to stabilize the variability inherent to the data. Averaging data enabled a concise statistical analysis that was not biased toward the months when more measurements were taken. We used a linear mixed model (PROC MIXED, SAS Institute, Cary, NC) to test for differences in depth to the water table over the 28 months of the study between both a priori and post hoc "frequently used" wetlands and wetlands "not known to be used." An autoregressive covariance structure was used to account for dependence between months. Individual wetlands within groups were modeled as a random effect. Mixed model analysis with autoregressive covariance was also used to compare the degree of surface saturation on a priori and post hoc wetland groupings over the six measurement events (recall that all post hoc comparisons had a reduced sample size as the two transiently used wetlands were removed). The average depth to the water table in summer (June-September) was compared among years (2007-2009) using a 1-way fixed-effect ANOVA.

We used Multiresponse Permutation Procedure (MRPP) (Blossom, U.S. Geological Survey, Fort Collins, CO) to test for statistical differences in the variance of depth to the water table between a priori and post hoc wetland groupings over the 28 months of the study. The MRPP is an effective way to test for differences in grouped data when sample sizes are small or distributions of the data are unknown. We used regression to model the relationship of percent surface saturation present in the vicinity of groundwater wells to the independent water table depth measurements. Unless noted, we completed statistical analyses using Minitab (Student Release 14, State College, PA).

The goal of this study was to identify biologically relevant attributes of wetlands that could be useful for management of a rare species. Data collected from hydrologic systems are inherently noisy, yet the large spatial scale of the study with individual wetlands as the replicated statistical unit necessitated a relatively low sample size. To balance the risk of Type II error (failing to detect a trend that is actually occurring in the data) versus Type 1 error (detecting a trend that is not true), we used an $\alpha \leq 0.1$ to indicate significance (Angermeier 1996; Beier et al. 2002).

\section{Results}

Rainfall Conditions

In 2005 and 2006, rainfall accumulation was 93 and $102 \%$ of the long-term average rainfall $(122 \mathrm{~cm})$, respectively.
Rainfall during the years of the study in 2007, 2008, and 2009 was 86,72 , and $97 \%$ of the long-term average, respectively. According to the distribution of PHDI values from 1895 through 2009, the probability of experiencing drier conditions than were measured during 2007, 2008, and 2009 were $0.08,0.03$, and 0.76 , respectively. Monthly PHDI values between -3.0 and -4.0 from September 2007 through March 2008 indicated severe drought conditions, while PHDI values between -2.0 and -3.0 from April through November 2008 indicated moderate drought conditions (Fig. 2a).

\section{Depth to Water Table}

Over the 28 months of record, average depth to the water table (+SE) was $-8.0 \mathrm{~cm} \pm 1.0 \mathrm{~cm}$ and $-11.4 \mathrm{~cm} \pm 1.6 \mathrm{~cm}$ for a priori frequently used wetlands $(n=6)$ and wetlands not known to be used $(n=6)$, respectively (Table 1 ). Average depth to the water table (+SE) was $-13.7 \mathrm{~cm} \pm 1.1 \mathrm{~cm}$ and $-6.9 \mathrm{~cm} \pm 1.0 \mathrm{~cm}$ for post hoc wetlands not known to be used $(n=4)$ and transiently used wetlands $(n=2)$, respectively (recall that frequently used wetlands are the same for both a priori and post hoc groups). Mixed model analysis, with turtle use status as the main effect over the 28 month study period, showed a difference $(3.4 \mathrm{~cm}$ on average) between depth to water table in a priori wetland groups $\left(F_{1,10}=3.56, P=0.0883\right)$ (Table 2$)$. We found stronger evidence of a difference $(5.7 \mathrm{~cm}$ on average) between post hoc wetland groups $\left(F_{1,8}=11.88, P=0.0087\right)$. The repeated, among-month effect (within individual wetlands) was significant for both a priori and post hoc comparisons $(P<0.0001)$. The interaction effect between repeated months and wetland groups was not significant for either a priori or post hoc comparisons $(P \geq 0.145)$.

The range of monthly water table depths was $-0.3 \mathrm{~cm}$ to $-32.7 \mathrm{~cm}$ and $-1.8 \mathrm{~cm}$ to $-37.4 \mathrm{~cm}$ for a priori frequently used wetlands $(n=6)$ and wetlands not known to be used $(n=6)$, respectively. The monthly water table depth ranged from $-1.7 \mathrm{~cm}$ to $-45.4 \mathrm{~cm}$ and $-1.0 \mathrm{~cm}$ to -21.3 for post hoc wetlands not known to be used $(n=4)$ and transiently used wetlands $(n=2)$, respectively (Fig. $2 b)$. Over the course of each study year, the lowest water levels occurred during August, while the highest levels occurred from March to May. In summer (June-September), average depth to the water table differed among the three years of the study for a priori frequently used wetlands $\left(F_{2,15}=13.06, P=0.001\right)$ and a priori wetlands not known to be used $\left(F_{2,15}=10.49, P=\right.$ 0.001). Summer water table depths were also different in the post hoc wetland groupings $\left(F_{2,9}=13.03, P=0.002\right)$. Multiple comparisons using Tukey's critical difference test indicated that differences occurred between the summer of 2007 and 2008 and 2008 and 2009 for all comparisons among wetlands with different bog turtle use status. No differences were detected between the summers of 2007 and 2009 . Depth to water table was the greatest in the summer of 

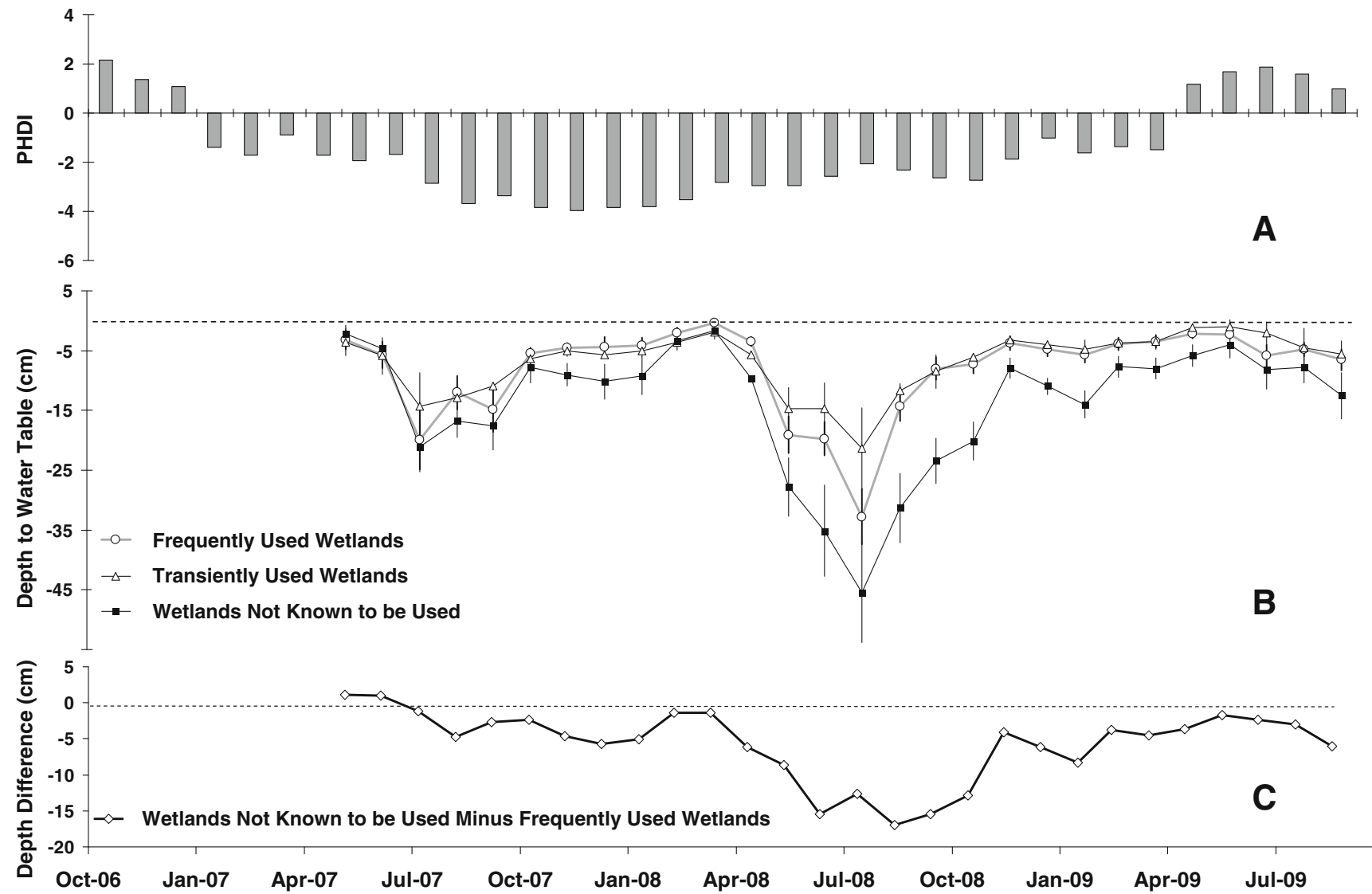

Fig. 2 a Monthly Palmer Hydrological Drought Index (PHDI) values before and during the study. Moderate $(-2.0$ to -3.0$)$ to severe $(-3.0$ to -4.0 ) drought conditions were present during the summer of 2007 and 2008. b Monthly average depth (error bars \pm SE) to water table on "frequently used wetlands" ( $n=6)$, "transiently used wetlands" $(n=2)$,

2008, when the overall mean depth of all study wetlands was $-25 \mathrm{~cm}$, and the average difference between water table depths was $13 \mathrm{~cm}$ (Figs. 2c and 3).

Variance in Depth to Water Table Over Time

The average among-months variance $( \pm$ SD) for a priori frequently used wetlands $(n=6)$ and wetlands not known and "wetlands not known to be used" $(n=4)$ as measured by shallow groundwater wells over the 28 -month study period. Soil surface is at zero and water table levels are negative values. $\mathbf{c}$ Mean difference in depth to water table between "wetlands not known to be used" and "frequently used wetlands"

to be used $(n=6)$ was $73.1 \mathrm{~cm}^{2} \pm 39.6 \mathrm{~cm}^{2}$ and $109.5 \mathrm{~cm}^{2} \pm$ $98.5 \mathrm{~cm}^{2}$, respectively (Table 1 ). The average amongmonths variance for post hoc wetlands not known to be used $(n=4)$ was $149.3 \mathrm{~cm}^{2} \pm 98.5 \mathrm{~cm}^{2}$. The average among-months variance for transiently used wetlands was $29.7 \mathrm{~cm}^{2} \pm 16.3 \mathrm{~cm}^{2}$. A statistical test that the variance differed on the a priori wetlands groups was not supported using MRPP $\left(\delta_{\text {observed }}=82.5, \delta_{\text {expected }}=85.0, P=0.248\right)$.
Fig. 3 Depth to the water table on 49 individual sampling events spanning May through October, 2008. Each data point represents the mean depth in either "frequently used wetlands" $(n=6)$, "transiently used wetlands" $(n=2)$, or "wetlands not known to be used" $(n=4)$. Daily rainfall totals are shown on the alternative $y$-axis

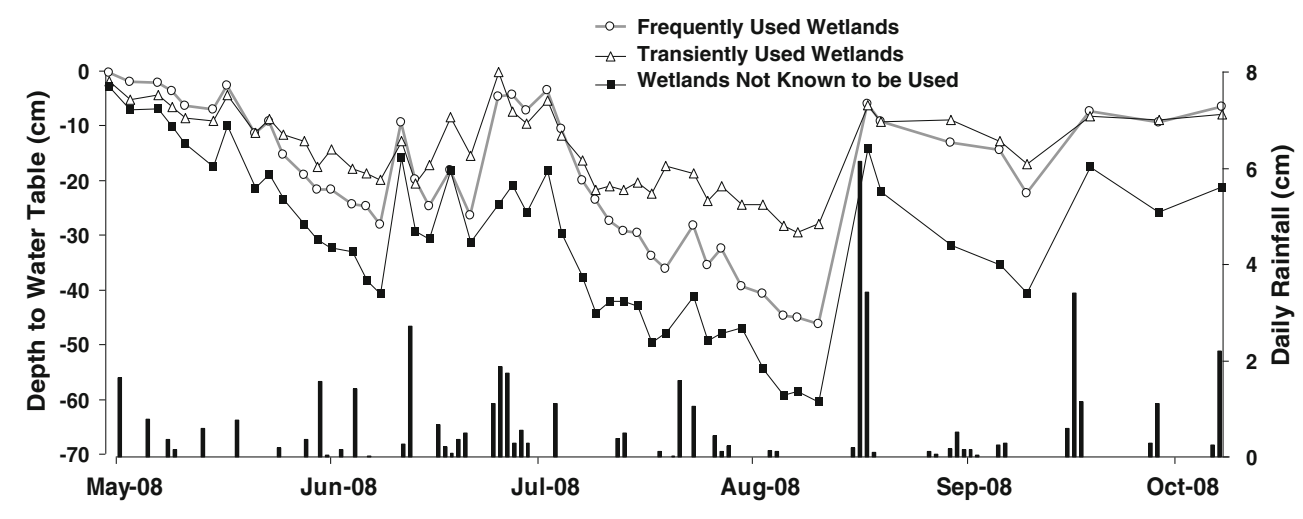


Table 1 Wetland size, number of groundwater monitoring wells and average monthly depth to water table (DTW) over the study. Bog turtle use status groups were "frequently used" (Frequent), "transiently used wetlands" (Transient), or wetlands "not known to be used" (Not
Known). Statistics for overall group variance, median, min, and max were calculated by averaging the individual wetland data over each of the 28 months and then tabulating statistics among months

\begin{tabular}{|c|c|c|c|c|c|c|c|c|c|c|}
\hline \multirow[b]{2}{*}{$\begin{array}{l}\text { Bog turtle use } \\
\text { status of wetland }\end{array}$} & \multirow[b]{2}{*}{$\begin{array}{l}\text { Size } \\
\text { (ha) }\end{array}$} & \multirow[b]{2}{*}{$\begin{array}{l}\text { Wells } \\
\text { installed }\end{array}$} & \multirow[b]{2}{*}{$\begin{array}{l}\text { Months } \\
\text { sampled }\end{array}$} & \multicolumn{5}{|l|}{ DTW } & \multirow[b]{2}{*}{$\begin{array}{l}\text { \% Months } \geq \\
-30.5 \mathrm{~cm}\end{array}$} & \multirow[b]{2}{*}{$\begin{array}{l}\% \text { Months } \geq \\
-15 \mathrm{~cm}\end{array}$} \\
\hline & & & & $\begin{array}{l}\text { Mean } \\
(\mathrm{cm})\end{array}$ & $\begin{array}{l}\text { Among-months } \\
\text { variance }\left(\mathrm{cm}^{2}\right)\end{array}$ & $\begin{array}{l}\text { Median } \\
(\mathrm{cm})\end{array}$ & $\begin{array}{l}\text { Min } \\
(\mathrm{cm})\end{array}$ & $\begin{array}{l}\text { Max } \\
(\mathrm{cm})\end{array}$ & & \\
\hline Frequent 1 & 0.48 & 6 & 28 & -3.8 & 8.8 & -3.3 & -13.3 & 0.4 & 100 & 100 \\
\hline Frequent 2 & 0.58 & 3 & 28 & -9.3 & 129.2 & -4.3 & -45.8 & 0.4 & 93 & 82 \\
\hline Frequent 3 & 1.27 & 7 & 28 & -11.1 & 83.2 & -7.0 & -35.9 & -0.6 & 96 & 71 \\
\hline Frequent 4 & 0.50 & 6 & 27 & -7.7 & 58.5 & -5.4 & -31.5 & 0.8 & 96 & 82 \\
\hline Frequent 5 & 0.44 & 8 & 28 & -8.1 & 67.1 & -5.6 & -41.7 & 1.4 & 96 & 93 \\
\hline Frequent 6 & 0.27 & 3 & 28 & -8.2 & 89.8 & -5.5 & -32.4 & 0.9 & 96 & 75 \\
\hline Frequent Overall & 0.59 & 33 & 28 & -8.0 & 54.1 & -5.1 & -32.7 & -0.3 & 96 & 86 \\
\hline Transient 1 & 0.12 & 3 & 28 & -5.9 & 18.2 & -5.8 & -14.6 & 0.1 & 100 & 100 \\
\hline Transient 2 & 0.22 & 3 & 28 & -7.8 & 41.2 & -5.4 & -28.1 & -1.9 & 100 & 86 \\
\hline Transient Overall & 0.17 & 6 & 28 & -6.8 & 24.6 & -5.3 & -21.3 & -1.0 & 100 & 96 \\
\hline Not Known 1 & 0.32 & 3 & 28 & -15.4 & 173.5 & -13.8 & -50.2 & 0.7 & 89 & 54 \\
\hline Not Known 2 & 0.58 & 3 & 28 & -10.7 & 15.8 & -9.5 & -22.9 & -4.7 & 100 & 93 \\
\hline Not Known 3 & 0.31 & 3 & 28 & -14.0 & 155.5 & -9.7 & -45.7 & 1.3 & 86 & 61 \\
\hline Not Known 4 & 0.62 & 3 & 28 & -14.7 & 252.6 & -7.7 & -62.9 & -0.2 & 86 & 71 \\
\hline Not Known Overall & 0.46 & 12 & 28 & -13.7 & 114.6 & -9.4 & -45.4 & -1.7 & 90 & 68 \\
\hline
\end{tabular}

However, this same test on post hoc wetland groups showed a difference between variances $\left(\delta_{\text {observed }}=77.0, \delta_{\text {expected }}=\right.$ $88.4, P=0.083)$.

\section{Surface Saturation}

Surface saturation was inversely proportional to the depth to the water table (Fig. 4a). Surface saturation of post hoc frequently used wetlands and wetlands not known to be used decreased with increasing depth to groundwater $\left(r^{2}=0.77\right)$. Average percent saturation near the wells over the six measurement events $( \pm$ SD) was $34 \% \pm 16,45 \% \pm 9$, and $20 \% \pm 17$ for post hoc frequently used wetlands, transiently used wetlands, and wetlands not known to be used, respectively. We did not detect a difference between surface saturation of a priori wetland groups $\left(F_{1,10}=0.83, P=0.3848\right)$ (Table 2). However, surface saturation of post hoc wetland groups differed $\left(F_{1,8}=\right.$ $3.70, P=0.091)$. The six repeated event measurements differed among both a priori and post hoc comparisons $(P<0.001)$. The interaction between bog turtle use status and repeated events was also significant for both a priori and post hoc comparisons $(P \leq 0.018)$. This interaction was attributed to the more pronounced drop in the water table (leading to less saturation) during the drought at wetlands not known to be used relative to frequently used wetlands (Fig. 4b).

\section{Discussion}

\section{Depth to Water Table}

The severe drought in 2007 and 2008 followed by average rainfall in 2009 enabled us to test for differences in hydrology at wetlands that were frequently used and not known to be used by bog turtles. We found evidence that wetlands frequently used by bog turtles had a greater (less negative) mean depth to the water table than wetlands not known to be used.

There was evidence that the difference in depth between post hoc wetland groups varied in response to drought over the course of the study; however, there was a time lag in the response. Despite drought conditions in 2007, it was not until 2008 that the largest water table effects were measured in the study wetlands (Fig. 2). The discrepancy between study groups was still evident at the end of the study despite the resumption of normal rainfall. This hydrologic response was likely related to reduced groundwater discharge in the four post hoc wetlands not known to be used by bog turtles. Declines in the water table in groundwater-driven wetlands would be expected to be more severe in wetlands that are recharged by local, rather than more widespread or regional groundwater flow systems (Bedford and Godwin 2003). Perhaps recharge areas are larger for frequently used 

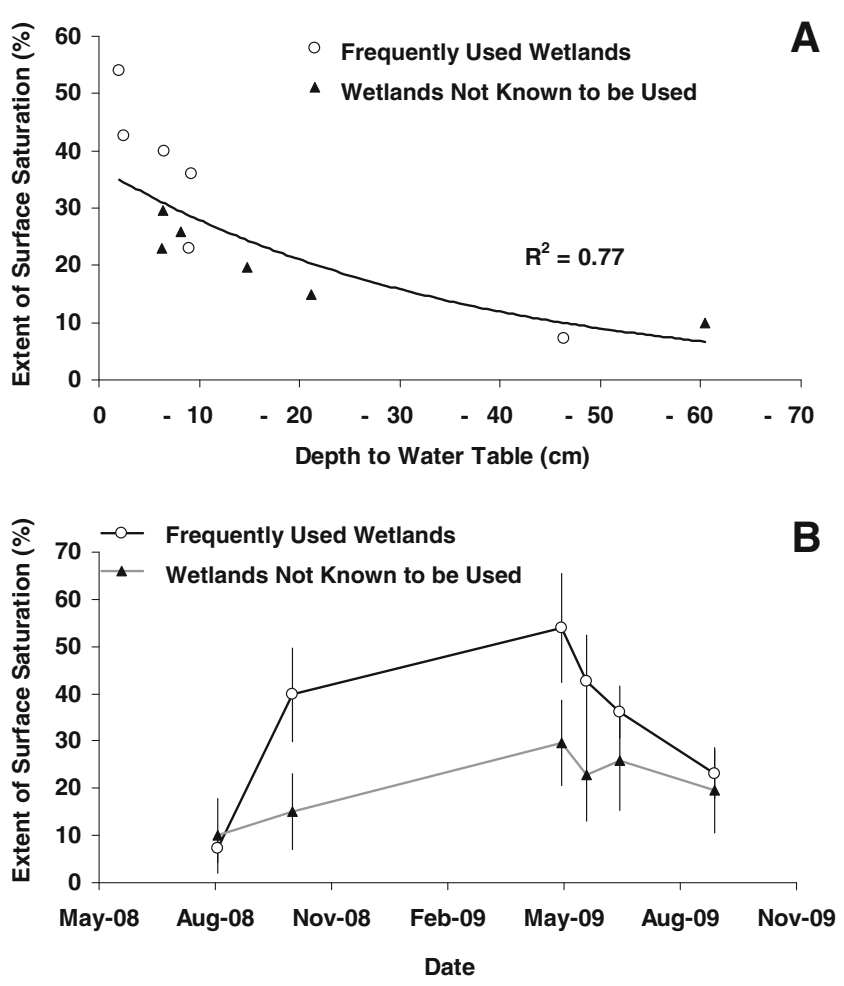

Fig. 4 a The decreasing and exponential relationship between depth to the water table and the proportion of saturated surface area near groundwater wells. Data measured on "frequently used wetlands" $(n=6)$ and "wetlands not known to be used" $(n=4)$. Soil surface is at zero and water table levels are negative values. b Percent saturated area near groundwater wells during six different events spanning August 2008 and August 2009. August 2008 was the month with the lowest saturated area and coincided with the period of the deepest water table

wetlands than wetlands not known to be used. Unfortunately, recharge areas are not easy to identify for fen wetlands (Bedford and Godwin 2003).

Event-based water table levels responded more rapidly during the peak of the drought in 2008 than did monthly water table averages, revealing information on differential response to drought and the importance of groundwater inflow (Fig. 3). Minor rain events during the summer of 2008 were not sufficient to maintain high water tables. Water inputs must first saturate the soil, exceed the evapotranspiration potential of wetland plants, and recharge groundwater flow systems before sustained water table increases can occur (Moorhead 2003). Water tables at all study wetlands were elevated to within $-15 \mathrm{~cm}$ of the surface following a $10 \mathrm{~cm}$ rain event at the end of August 2008. Frequently used wetlands sustained these water table levels throughout the following months, yet water tables at post hoc wetlands not known to be used by turtles were elevated only briefly before dropping once again (Fig. 3). The immediate response of frequently used wetlands to rainfall may appear contrary to expectations of a groundwaterdriven wetland; however, in a southern Blue Ridge fen in North Carolina, Moorhead (2001) also observed rapid water table response to rainfall following a drought. In that study, well transects parallel to the slopes surrounding the wetland showed that rainfall increased shallow groundwater flow to the wetland.

Comparison of Among-Months Variance of Depth to Water Table

The variance of depth to the water table at post hoc wetlands not known to be used by turtles was twice that of frequently used wetlands; however, we did not find a difference in variance between the a priori wetland groups. The transiently used wetlands actually had the lowest variances of all study wetlands (as well as the highest water tables), providing evidence that factors other than hydrology may influence use of these wetlands by bog turtles. For the remaining four post hoc wetlands not known to be used, the large variances in the depth to the water table were likely related to reduced
Table 2 Results of linear mixed modeling used to test for differences in depth to water table and surface saturation in wetlands frequently used and not known to be used by bog turtles. All tests were run on a priori and post hoc wetland groups with an autoregressive covariance structure used over the 28 months of water table measurements or six saturation measurement events

\begin{tabular}{llllll}
\hline Variable & Wetland groups & Source & $d f$ & $F$ & $P$-value \\
\hline Depth to water table & \multirow{2}{*}{ a priori } & Use status & 1,10 & 3.56 & 0.088 \\
& & Month & 27,269 & 23.86 & $<0.001$ \\
& \multirow{3}{*}{ post hoc } & Use status x Month & 27,269 & 0.97 & 0.510 \\
& & Use status & 1,8 & 11.88 & 0.009 \\
& & Month & 27,216 & 20.20 & $<0.001$ \\
Surface saturation & \multirow{3}{*}{ a priori } & Use status x Month & 27,216 & 1.32 & 0.145 \\
& & Use status & 1,10 & 0.83 & 0.355 \\
& & Event & 5,50 & 8.77 & $<0.001$ \\
& \multirow{3}{*}{ post hoc } & Use status x Event & 5,50 & 3.05 & 0.018 \\
& & Use status & 1,8 & 3.70 & 0.091 \\
& & Event & 5,40 & 9.48 & $<0.001$ \\
& & Use status x Event & 5,40 & 3.43 & 0.011 \\
\hline
\end{tabular}


groundwater inflow, greater surface water contributions, and greater response to drought.

Although the original formation of soils in most fen wetlands of the study region is associated with flood deposited alluvium, these wetlands do not currently exhibit frequent flooding (Weakley and Schafale 1994). We observed the study wetlands during and within several hours of intense rain events in the spring and summer of 2009 when most wetlands were already saturated to the surface, and did not observe inundation greater than approximately $20 \mathrm{~cm}$. The absence of frequent overbank flooding may be an important feature of bog turtle habitat, as flooding could alter soils or lead to losses of nests or even adult turtles.

Surface Saturation - the Link between Hydrology and Bog Turtle Use?

A potential link between water table hydrology and wetland use by bog turtles is surface saturation. Surface saturation near wells at frequently used wetlands decreased from approximately $50 \%$ to $25 \%$ when the depth to water table dropped from 0 to $-15 \mathrm{~cm}$, and our data suggest that surface saturation could diminish to approximately $10 \%$ if the water table dropped to $-50 \mathrm{~cm}$. We found that the wetlands frequently used by bog turtles rarely exhibited conditions where surface soil saturation was not permanent within some portion of the wetland. Only one frequently used wetland showed complete surface drying during the peak of the drought in August 2008. In response, radio-tagged bog turtles monitored at this site moved to either a stream or a saturated roadside ditch (Feaga 2010). In contrast, two wetlands not known to be used by bog turtles were completely dry on the surface during the summer of 2008, and one of these wetlands never regained surface saturation after normal rainfall resumed in 2009.

Bog turtles use saturated areas within wetlands, even when availability of these habitats is limited (Carter et al. 1999; Feaga 2010). In summer, when conditions are driest, bog turtles were nearly always found from 0 to $-15 \mathrm{~cm}$ below the surface and typically in saturated locations. In winter, turtles hibernate in saturated areas from -5 to $-45 \mathrm{~cm}$ below the surface, with many hibernating between 0 and $-15 \mathrm{~cm}$ (Chase et al. 1989; Feaga 2010). We found that the depth to water table remained above $-15 \mathrm{~cm}$ for 86 , 96 , and $68 \%$ of the 28 months of this study on post hoc frequently used wetlands, transiently used wetlands, and wetlands not known to be used, respectively. These depthrelated behaviors may indicate that nearly continuous saturation in the upper soil is critical for bog turtle survival and fitness. Saturated soil enables turtles to submerge themselves in mud to avoid predators, remain hydrated, and allows turtles to avoid extremes in temperature during the summer and winter. The availability of saturated areas may ultimately explain why some wetlands consistently support bog turtles, while others do not.

Human activities that alter water table hydrology and surface saturation in fen wetlands include ditching, tiling, or creation of ponds. Such alterations are a common occurrence on farmlands in the region. Natural disturbances such as drought or construction of dams by beavers (Castor canadensis) also alter the local water table. As fen hydrology is dependent on the entire drainage area, even activities outside of the wetland can induce changes to hydrology (Richardson and Gibbons 1993). Such changes could reduce bog turtle use of wetlands or even render wetlands uninhabitable. Large areas of standing water or inundation were not characteristics associated with wetlands frequently used by bog turtles. Therefore, creation of impervious surfaces, which can lead to short periods of inundation in wetlands from extremely high surface flows, may influence bog turtle use of wetlands. Torok (1994) associated the extirpation of bog turtles from a New Jersey wetland to storm water diversions that caused high velocity channelized flow. An analysis of hydrogeology in Maryland found that highway construction and other development activities within the recharge area of a bog turtle wetland had a high likelihood of causing detrimental impacts to the existing wetland hydrology (Brennan et al. 2001). The study found that reduced recharge would not have a great effect on water table levels, but that reduced head pressure in the crystalline metamorphic rock aquifer would reduce groundwater discharge to the wetland.

\section{A Broader View of the Study Wetlands}

The original a priori assignments of bog turtle wetland use in this study have biological relevance. Only the a priori used wetlands had potentially viable bog turtle populations where evidence of nesting and recruitment were observed (Feaga 2010). Only a fraction of the wetlands available in the landscape support bog turtles of all life stages. Despite the evidence from our post hoc analysis indicating that hydrology is a factor in bog turtle wetland use, other factors not measured in this study may also influence patterns of bog turtle use of wetlands in the region. Transiently used wetlands had high, stable water tables, yet apparently did not provide nesting habitat for bog turtles (Feaga 2010). Nonetheless, these wetlands may be important for bog turtles, possibly by providing temporary habitat for dispersing juveniles or breeding adults as they move between more suitable wetlands (Gahl et al. 2009). Transiently used wetlands may also act as refuges for turtles during drought, or could ultimately provide future habitat as conditions change within a dynamic landscape (Buhlmann et al. 1997).

Independent of bog turtle use status, the study wetlands exhibited some common characteristics that set them apart 
from the wide array of wetland types present throughout the study region. While one of the minimum criteria to define a wetland is a water table above $-30.5 \mathrm{~cm}$ for only two weeks of the growing season (Wetland Training Institute, Inc. 1995), monthly water tables in the 12 wetlands included in this study remained above $-30.5 \mathrm{~cm}$ for greater than $90 \%$ of the 28-month study period. This study did not include wetlands that would classify as in-stream floodplain or fringing wetlands, which are present throughout the Appalachian region (Cole et al. 2008). None of the wetlands investigated in our research were associated with 4th order streams or greater in USGS 7.5' quadrangle maps (Feaga 2010). The groundwater-driven wetlands in headwater positions that are used or potentially used by bog turtles in Virginia are themselves relatively rare resources that are capable of providing the specific habitat requirements of the rare bog turtle (Rabinowitz 1981).

\section{Conclusions}

Differences in water table hydrology and surface saturation were observed between wetlands frequently used by bog turtles and wetlands not known to be used. These differences were not apparent at the onset of the study prior to a regional drought, suggesting that differences in surface hydrology among the wetlands may be difficult to detect, or may only exist during drought. Wetlands frequently used by bog turtles would be expected to be hydrologically buffered from drought conditions and also to rebound quickly once normal weather patterns are resumed. We suggest that water table hydrology and related surface saturation may present a limiting factor for bog turtle use at the wetland scale. On a larger scale, the types of wetlands that provide current or potential habitat for bog turtles display a different pattern of hydrology relative to other types of wetlands available in the region.

This study provides baseline hydrological data for wetlands used by bog turtles in the southern Blue Ridge subprovince of Virginia. These data are important for any future mitigation or restoration projects that impact bog turtle wetlands. Such projects should recognize that mitigation design criteria related to bog turtles are more limiting than the minimum criteria used to define a wetland (Wetland Training Institute, Inc. 1995). This study also provides a reference as to the degree of short-term (on the order of one or two years) water table reductions and related saturation reductions that can be experienced by wetlands supporting breeding populations of bog turtles. According to PHDI data, the level of drought experienced during this study only occurs about three or four times each century. We suggest that activities that potentially alter wetland hydrology beyond the parameters observed in this study, in magnitude and duration, would drastically alter habitat suitability for bog turtles.

Acknowledgments Funding for this research was provided by the United States Fish and Wildlife Service through a State Wildlife Grant administered by the Virginia Department of Game and Inland Fisheries (VDGIF). We thank the National Park Service (NPS), Virginia Polytechnic Institute and State University (Virginia Tech), and M. Pinder for their logistical support and grant administration. We thank E. Matusevich, G. Laing, E. Owens, J. Stills, J. Goodhart, J. Marshall, C. Walker, and J. West for field assistance. We thank T. Gorman for manuscript comments. This research was conducted under NPS Permit BLRI-2006-SCI-0029, VDGIF permits 31313, 33376, and 36243, and Virginia Tech Institutional Animal Care and Use Committee Protocol 07-057-FIW.

Open Access This article is distributed under the terms of the Creative Commons Attribution License which permits any use, distribution, and reproduction in any medium, provided the original author(s) and the source are credited.

\section{References}

Amon JP, Thompson CA, Carpenter QJ, Miner J (2002) Temperate zone fens of the glaciated Midwestern USA. Wetlands 22:301317

Angermeier PL (1996) Ecological attributes of extinction-prone species: loss of freshwater fishes of Virginia. Conservation Biology 9:143-158

Bedford BL, Godwin KS (2003) Fens of the United States: distribution, characteristics, and scientific connection versus legal isolation. Wetlands 23:608-629

Beier P, van Drielen M, Kankam BO (2002) Avifaunal collapse in West African forest fragments. Conservation Biology 16:1097-1111

Brennan KE, O'Leary DJ, Buckley SP (2001) Hydrologic analysis of the wetland habitat of the federally threatened bog turtle. In: Irwin CL, Garrett P, McDermott KP (eds) 2001 International Conference on Ecology and Transportation. John Muir Institute of the Environment, North Carolina State University, Raleigh, pp 51-64

Buhlmann KA, Mitchell JC, Rollins MG (1997) New approaches for the conservation of bog turtles, Clemmys muhlenbergii, in Virginia. In: VanAbbema J (ed) Proceedings: conservation, restoration, and management of tortoises and turtles: An International Conference. New York Turtle and Tortoise Society, New York, pp 359-363

Bury RB (1979) Review of the ecology and conservation of the bog turtle Clemmys muhlenbergii. U.S Fish and Wildlife Service, Special Scientific Report. Wildlife 219:1-9

Carter SL, Haas CA, Mitchell JC (1999) Home range and habitat selection of bog turtles in southwestern Virginia. Journal of Wildlife Management 63:853-860

Carter SL, Haas CA, Mitchell JC (2000) Movements and activity of bog turtles (Clemmys muhlenbergii) in southwestern Virginia. Journal of Herpetology 34:75-80

Chase JD, Dixon KR, Gates JE, Jacobs D, Taylor GJ (1989) Habitat characteristics, population-size, and home range of the bog turtle, Clemmys muhlenbergii, in Maryland. Journal of Herpetology 23:356-362

Cole CA, Cirmo CP, Wardrop DH, Brooks RP, Peterson-Smith J (2008) Transferability of an HGM wetland classification scheme to a longitudinal gradient of the central Appalachian Mountains: Initial hydrological results. Wetlands 28:439-449 
Ernst CH, Lovich JE (2009) Turtles of the United States and Canada, 2nd edn. The Johns Hopkins University Press, Baltimore

Feaga JB (2010) Wetland hydrology and soils as components of Virginia bog turtle (Glyptemys muhlenbergii) habitat. Dissertation. Virginia Polytechnic Institute and State University, Blacksburg

Gahl MK, Calhoun AJK, Graves R (2009) Facultative use of seasonal pools by American bullfrogs (Rana catesbeiana). Wetlands 29:697-703

Gibbons JW (1990) Life history and ecology of the slider turtle. Smithsonian Institution Press, Washington

Gu WD, Swihart RK (2004) Absent or undetected? Effects of nondetection of species occurrence on wildlife-habitat models. Biological Conservation 116:195-203

Herman DW, Tryon BW (1997) Land use, development, and natural succession and their effects on bog turtle habitat in the southeastern United States. In: VanAbbema J (ed) Proceedings: conservation, restoration, and management of tortoises and turtles: An International Conference. New York Turtle and Tortoise Society, New York, pp 364-371

Hunt RJ, Walker JF, Krabbenhoft DP (1999) Characterizing hydrology and the importance of ground-water discharge in natural and constructed wetlands. Wetlands 19:458-472

Lee DS, Norden AW (1996) The distribution, ecology and conservation needs of bog turtles, with special emphasis on Maryland. The Maryland Naturalist 40:7-46

Mitchell JC (1994) The reptiles of Virginia. Smithsonian Institution Press, Washington

Moorhead KK (2001) Seasonal water table dynamics of a southern Appalachian floodplain and associated fen. Journal of the American Water Resources Association 37:105-114

Moorhead KK (2003) Effects of drought on the water-table dynamics of a southern Appalachian mountain floodplain and associated fen. Wetlands 23:792-799

National Climatic Data Center (2010) U.S. Department of Commerce. Palmer Hydrological Drought Index. Available http:// www1.ncdc.noaa.gov/pub/data/cirs/. (Accessed: 5 April 2010)
National Weather Service (2010) National Oceanic and Atmospheric Association, U.S. Department of Commerce. Available http:// www1.ncdc.noaa.gov/. (Accessed: 3 March 2010)

Natureserve (2009) Natureserve Web Service. Arlington, VA. USA Available http://services.natureserve.org. (Accessed: 19 March 2009)

Rabinowitz D (1981) Seven forms of rarity. In: Synge H (ed) The biological aspects of rare plant conservation. Wiley \& Sons, Ltd., Chichester, pp 205-217

Richardson CJ, Gibbons JW (1993) Pocosins, Carolina bays and mountain bogs. In: Martin WH, Boyce SG, Echternacht AC (eds) Biodiversity of the Southeastern United States: lowland terrestrial communities. Wiley, New York, pp 257-310

Roe JH, Georges A (2008) Maintenance of variable responses for coping with wetland drying in freshwater turtles. Ecology 89:485-494

Shaffer PW, Cole CA, Kentula ME, Brooks RP (2000) Effects of measurement frequency on water-level summary statistics. Wetlands 20:148-161

Skidds D, Golet F (2005) Estimating hydroperiod suitability for breeding amphibians in southern Rhode Island seasonal forest ponds. Wetlands Ecology and Management 13:349-366

Somers AB, Mansfield-Jones J (2008) Role of trapping in detection of a small bog turtle (Glyptemys muhlenbergii) population. Chelonian Conservation and Biology 7:149-155

Tesauro J, Ehrenfeld D (2007) The effects of livestock grazing on the bog turtle [Glyptemys (= Clemmys) muhlenbergii]. Herpetologica 63:293-300

Torok LS (1994) The impacts of storm water discharges on an emergent bog community featuring a population of the bog turtles (Clemmys muhlenbergii) in Gloucester County, New Jersey. Bulletin of the Maryland Herpetological Society 30:51-61

Weakley AS, Schafale MP (1994) Non-alluvial wetlands of the Southern Blue Ridge: diversity in a threatened ecosystem. Water, Air, and Soil Pollution 77:359-383

Wetland Training Institute, Inc (1995) Field Guide for Wetland Delineation; 1987 Corps of Engineers Manual. 02-1 edition. Wetland Training Institute, Inc., Glenwood, NM, USA 